Volume 13 Number 4, October-December 2019: pp. 361-380. Copyright (c) 2019 FIAT JUSTISIA. Faculty of Law, Lampung University, Bandarlampung, Lampung, Indonesia. ISSN: 1978-5186 | e-ISSN:2477-6238. Open Access: http://jurnal.fh.unila.ac.id/index.php/fiat

Fiat Justisia is licensed under a Creative Commons Attribution 4.0 International License, which permits unrestricted use, distribution, and reproduction in any medium, provided the original work is properly cited.

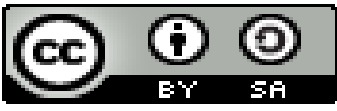

\title{
Political Law of Sidawangi Society towards Customary Rights Over Oro-Oro Land
}

\author{
Sarip \\ Universitas Muhammadiyah, Indonesia \\ sarip@umc.ac.id \\ Hanif Nurcholish Adiantika \\ Universitas Muhammadiyah, Indonesia \\ hanifadiantika@gmail.com \\ Abdul Muaz \\ Universitas Muhammadiyah, Indonesia \\ muaz@umc.ac.id
}

\begin{abstract}
The study concerning political law of Sidawangi society towards customary right over "Oro-Oro" land is commonly triggered by the presence of the arbitrary village officers. Historically, "Oro-Oro" land is characterised as a communal land, but its management is initiated exclusively through an agreement and doubtful rights. The legal law concerning customary right over "Oro-Oro" land is truly expected by Sidawangi society. The action of arbitrary village officers is deemed to be one of crucial factors to realise their expectation.

Furthermore, the rumour of switching "Oro-Oro" land into plantation land by the corporation also toughens the strong desire of Sidawangi society to realize their expectation. The present study aims to investigate the significance of legal law and the warranty of customary rights both in the 1945 Constitution, agrarian law and international conventions. This study is conducted through an interview to Sidawangi society and literature studies regarding customary right over "Oro-Oro" land as expected by Sidawangi society. Customary right over "Oro-Oro" land, initiated by Sidawangi Society in Sumber Sub-District, originally refers to a communal area which has been exclusively possessed. In other words, this type of land is not privately
\end{abstract}


preserved. The people in Sidawangi society are only allowed to maintain and gather the result. The arbitrary of village officers seize trees in "Oro-Oro" land without any kinds of certain customary right. The phenomenon in Lampung has provided insight regarding the conflict occurs when the people expect is not fulfilled. The residents inevitably expect the existence of political law in society towards customary land. The legal protection towards customary right over "Oro-Oro" land is essentially guaranteed by 1945 constitution, Basic Agrarian Law Constitution, and international convention of indigenous community.

Keywords: Oro-Oro, Ulayat, Customary, Expectation.

How to Cite: Sarip, Hanif Nurcholish Adiantika, Abdul Muaz, "Political Law of Sidawangi Society Towards Customary Rights Over Oro-Oro Land", Fiat Justisia, 13 (4), (2019).

DOI: 10.25041/fiatjustisia.v13no4.1703

\section{A. Introduction}

Customary right (hak ulayat) $)^{1}$ is defined as a right of customary communities overall agrarian resources inside the territory of related customary law community. The object of customary right (hak ulayat) consists of any kind of agrarian resources (i.e. earth, water, and entire natural resources in that territory). ${ }^{2}$ Customary right is not designed and created by the authority officials. Instead, it occurs and cultivates (able also to disappear) in a certain territory which is in line with the existence and development of the life of its related customary community law. By the international convention of indigenous and tribal people or community established in June 1989 in Geneva, Switzerland. ${ }^{3}$ There are some conditions which oblige

\footnotetext{
${ }^{1}$ Customary right is defined as the right possessed by a customary law community to control land and its substances in their own territory; hak pertuanan; hak purba, https://www.kbbi.web.id/hak. Accessed February 22, 2018. See Muhammad Zakie, "Konflik Agraria Yang Tak Pernah Reda", Jurnal Legality, 1 (1), (2016), p. 45.

2 Ilyas Ismail, "Kedudukan dan Pengakuan Hak Ulayat Dalam Sistem Hukum Agraria Nasional", KANUN Journal, 12 (1), (2010), p. 50. See also Muslim Andi Yusuf, "Kepastian Hukum Hak Masyarakat Hukum Adat Atas Tanah Dan Sumber Daya Alam", National Seminar Proceeding Cokroaminoto University, 2 (1), p. 675, states that "Land is Mother" for customary law community that gives them life, food, place where they live with their ancestors which is something magical and sacred where their spirits must be protected and preserved. See also Article 33 Paragraph (3) of the 1945 Constitution.

${ }^{3}$ Indigenous and Tribal people are translated into 'Masyarakat Hukum Adat' which is relevant with the terms used by the National Human Rights Commission and the Constitutional Court.
} 
government to respect the significance of the specific cultural and spiritual values of the related customary law community. These conditions are concerned with their association with land or territory or, mainly, the collective aspects of this relationship. ${ }^{4}$

The government must initiate necessary actions to recognise a land which is traditionally occupied by the related customary law community. ${ }^{5}$ The government must also guarantee effective protection towards their rights on what they possess and what they regulate. ${ }^{6}$ According to customary law system as proposed by Ilyas Ismail, there are two types of customary right over land. They are: ${ }^{7}$

1. Customary right over land which is mutually organized by an indigenous or tribal community law which is called customary right inside the circumstance of a juridical technical term.

2. Customary right over land which is exclusively owned.

"Oro-Oro" land is customary land, located in Sidawangi Village Sumber Sub-District Cirebon Regency, which is exclusively owned by individuals. At the beginning of 1950s, "Oro-Oro" land was mutually maintained and commonly used for cattle purpose. ${ }^{8}$ Formerly, after 1960, the area was exclusively controlled by individuals based on the community right over land under community agreement. ${ }^{9}$ This agreement subsequently triggered a conflict towards "Oro-Oro" land. In 2010, the village side decided to forcibly cut logs around the territory of "Oro-Oro" land with an excuse on the

Any other common translations used are 'Masyarakat Adat' and 'Masyarakat Tradisional'. See also Article 33 of the 1945 Constitution.

${ }^{4}$ The 1989 Indigenous and Tribal People Convention Article 13 Paragraph (1).

${ }^{5}$ FX. Sumarja, Muhammad Akib, "Forest Resources Access Moro-Moro Farmers at Register 45 Lampung”, Journal Fiat Justisia, 12 (1), (2018), p. 10.

${ }^{6}$ The 1989 Indigenous and Tribal People Convention Article 14 Paragraph (2).

${ }^{7}$ Ilyas Ismail, Loc. Cit.

${ }^{8}$ Other regions like Indramayu also uses the term 'Tegal Pangonan' Radar Cirebon News, December $6^{\text {th }}$, 2013. There is a difference definition according to http://www.kamusbesar.com/58452/anah-tegalan that defines 'Tegal Pangonan' as a vast and flat land planted by secondary crops that depends on rain without irrigation system. The cattle in Sidawangi village are mostly buffaloes, sheep, and goats. Interview obtained from Warda, Misja, Miah, Pandi, and Asda as the "Oro-Oro" land owners with community agreement evidence towards the cultivators' rights border established communally by the people of Sidawangi village, December $2^{\text {nd, }} 2017$.

${ }^{9}$ This adjustment mostly due to the management of "Oro- Oro" land management possessed by individuals with the boundaries approved by the community itself. The cultivators as the management community can only gather the resources while on the other hand the land belongs entirely to the village. Besides, the land is not equipped with a legal formal letter from the village concerning management rights over land. The village side only carries out ineffectual data collection. Obtained from the conversation among the "Oro-Oro" land owners in Sidawangi village on January $20^{\text {th }}, 2018$. 
revitalization of village hall. ${ }^{10}$ There was nothing they could do to encounter this situation but complain. The village government stated the people firmly by emphasising them that the land belonged to the State. Besides, they also stressed that the people did not have written evidence concerning the customary right over "Oro-Oro" land.

The issue was even getting more intense until 2016 where "Oro-Oro" land would be taken over for agricultural estate business. ${ }^{11}$ This situation was truly problematic for the people, and it was indeed against the customary right over land as it is in line with the international convention of indigenous community on June $27^{\text {th }}, 1989$ in Geneva, Switzerland, 1945 constitution particularly Article 18 B Paragraph (2) and Article 33 Paragraph (3). Legality on customary right over "Oro-Oro" land was a fundamental constituent to provide legal conviction as well as legal protection to the owners regarding customary right over certain land. ${ }^{12}$ Both the legal conviction and legal protection are undeniably expected by the people who work in "Oro-Oro" land. "Oro-Oro" land, which is a lifeless object, inevitably requires evidence to emphasise that it is cultivated and controlled. The evidence also plays a crucial role to evade disagreement between the community and the side of village government. ${ }^{13}$ Managing "Oro-Oro" land also means requiring a legal and concrete political law. In other words, the legal certainty of "Oro-Oro" land can be fully and officially owned only if the evidence, in form of legal politics, exists. Hence, the necessity of political law, as crucial law instruments, is critically required to deal with claims directed by the arbitrary of village officers or any kind of outsiders towards the customary right over "Oro-Oro" land.

However, the people do not acquire the customary right over "Oro-Oro" land as a form of legality they have desperately expected even until $2018 .{ }^{14} \mathrm{It}$ is by Sunaryati Hartono that political law plays an essential role as a tool or means and steps utilized by the government to generate preferred national legal system. The national legal system is also employed to realize the ideals

\footnotetext{
10 There is an agreement with the owners of "Oro-Oro" land before cutting down the trees. However, the execution is not relevant with the agreement, Pandi's interview, December $18^{\text {th }}$, 2017.

${ }^{11}$ Supposedly, Sidawangi village government counts on the legal law, Ministry of Forestry Regulation Number: P. 49/menhut-II/2008 regarding Village Forests.

${ }^{12}$ The implementation of this land is generally in line with Article 19 of the 1960 Basic Agrarian Law Constitution Number 5.

${ }^{13}$ See and compare to Indah Mahniasari, "Pendaftaran Tanah Adat", Al' Adl Journal, 5 (9), (2013), p. 23.

${ }^{14}$ Some replacements of the Village Chief, in Sidawangi village, have been initiated. Karsa (the Village Chief who typically insists the people of Sidawangi with intimidation) is subsequently replaced by Alfan Nasuha, Laju, and currently Yoni. Nevertheless, the legal conviction as a legal political ideal for the cultivators' community in "Oro-Oro" land has not been fulfilled yet, the interview with Tarsan, Misja, Karwasih, Sanding, Tani, and Rusmana, January $21^{\text {st }}$, (2018).
} 
of the Nation of Indonesia. ${ }^{15}$ The owners' legality of "Oro-Oro" land is relevant with 1945 Constitution and the Convention of Customary Law particularly in Articles 13 and 14. Federal law is a mandatory part of realising law ideals, equal, beneficial and guaranteed as a dignified legal trinity. ${ }^{16}$ According to the problems as stated aforementioned, therefore, the issues can be formulated as follow: (1) what is the role of political law to terminate the conflict between the village side and the owners of "Oro-Oro" land? (2) What kind of results about the conflict of customary right over "Oro-Oro" land according to the International convention of indigenous community and Indonesian agrarian law to guarantee legal conviction to the customary right over "Oro-Oro" land?

\section{B. Research Methods}

The present study, which is concerned with the political law of customary right over "Oro-Oro" land, is characterised as field research. This study is carried out in Sidawangi Village Sumber Sub-District Cirebon Regency, West Java. An in-depth interview is employed to obtain comprehensive data from the community who own the customary right over "Oro-Oro" land. The informants, either as the side who generates the policy or the community affected by government policy of Sidawangi village, are also involved in this study. According to Soerjono Soekanto, this study is categorized as sociological or empirical legal research. On the other hand, SoetandyoWigjosoebroto classifies this study as non-doctrinal legal research which is defined as empirical studies to acquire the theories regarding the process of how a law is constructed and how it runs in a society. Secondary data can be observed from the book central theme or any other related documents. ${ }^{17}$

\section{Discussion}

\section{Legal Politic/Political Law of "Oro-Oro" Land Cultivators}

Sidawangi Village is geographically located in Sumber Sub-District Cirebon Regency, West Java Province. It is bordered to the south by Matanghaji Village, Sumber District and Nanggela Village, Mandirancan

\footnotetext{
${ }^{15}$ See Political Definitions, Law and Politics of Law in Yurisprudence on May $12^{\text {th }}, 2010$ http://bunga-legal.blogspot.co.id/2010/05/definisi-politik-hukum-dan-politik.html. Accessed February $1^{\text {st }},(2018)$.

16 Teguh Prasetyo, Keadilan Bermartabat Persefektif Teori Hukum, Bandung:Nusamedia, (2015), p. 112.

${ }^{17}$ Bambang Sugono in Aermadepa, "Perlindungan Hak Konstitusional Masyarakat Hukum Adat Minangkabau dalam Pelaksanaan Gadai Tanah Pertanian”, Konstitusi Journal, 13 (3), (2016), p. 603.
} 
District, Kuningan Regency. Subsequently, it is bordered to the east by Kubang Village, Talun District, and Cirebon Regency. It is bordered to the north by Sumber Village which is the capital of Cirebon Regency and Babakan Village, Sumber District. At last, it is bordered to the west by Cisaat Village, Dukupuntang District.

There are approximately 37 cultivators of "Oro-Oro" land in Sidawangi Village which is inherited previously by their elders. "Oro-Oro" land is inherited based on the bloodline or direct parents. Oro-Oro land can even be handed over by paying the maintenance cost based on the agreement with both sides. In 2010, Sidawangi government harvested various trees such as Jati, Arbiseand Mahogany with an excuse that Oro-Oro land belonged to state land, so that the Sidawangi government could harvest anything in Oro-Oro land. If the cultivators refused to hand over, they would be heavily fined and considered to be against the law. Consequently, the tress in Oro-Oro land was sold to the woodmasters. The people who replaced the buildings with planted wood eventually discontinued the process of house revitalisation because the tress around "Oro-Oro" land was forcibly seized by village side.

The excuse, concerning the village hall revitalisation stated by the village government side, caused dissatisfaction among "Oro-Oro" land cultivators. ${ }^{18}$ The pressures toward the cultivators existed even until 2016. The village side arbitrarily attempted to switch "Oro-Oro" land into plantation managed by private company. Fortunately, the cultivators were lucky because the village officer was dismissed as well as the village head. ${ }^{19}$ However, the people around the village were still anxious and kept attempting to search for legal conviction through political law until 2018.

Political law, as stated by Sunaryati Hartono, emphasizes the government policies implemented in society. In line with Hartono, Soedarto delineates that political law is concerned with government policies through authorized state structure. In addition, political law occurs to determine the regulations implemented to express what is inside the society and achieving what is expected. ${ }^{20}$. It is also relevant with Mahfud MD who emphasizes it on the lawmaker institution. ${ }^{21 .}$ The definition of political law proposed by Satjipto

\footnotetext{
${ }^{18}$ Cf Irsyad Martias, "Implikasi Perubahan Tata Guna Lahan Terhadap Dinamika EkonomiSosial Masyarakat Gunung Kidul: Suatu Kajian Antropologi Keruangan”, Jurnal BioKultur, 3 (1), (2014), pp. 292-315.

${ }^{19}$ Sarip, "Produk Hukum Pengkebirian Pemerintahan Desa", Jurnal Hukum\&Pembangunan, 49 (1), 2019, p. 63.

${ }^{20}$ Soedarto, Hukum Pidana dan Perkembangan Masyarakat dalam Kajian Hukum Pidana, Bandung: Sinar Baru, (1983), p. 20.

${ }^{21}$ See Moh. Mahfud MD, Politik Hukum di Indonesia, Jakarta: LP3ES, (1998), see also Moh. Mahfud MD as cited in Wahyu Nugroho, "Politik Hukum Pasca Putusan Mahkamah Konstitusi atas Pelaksanaan Pemilu dan Pemilukada di Indonesia", Konstitusi Journal, 13 (3), (2016), pp. 480-502.
} 
Rahardjo is at least in line with the expectation of the cultivators in "Oro-Oro" land. It involves the activity of choosing the procedure to achieve social purposes and specific law in society. ${ }^{22}$

Political law should be implemented for the cultivators' side in the name of justice, benefit, and certainty of the law itself to realise the certainty of the expected law by the cultivators in "Oro-Oro land". Political law is a process of critical and integrated investigation continually. The investigation is conducted based on what cultivators expect. ${ }^{23}$

According to the data obtained from the research site, "Oro-Oro" land is characterised as tegal pangonan. ${ }^{24}$ Tegal Pangonan refers to a land used for cattle purpose. Tegal Pangonanis exclusively owned by individuals based on the agreement of customary right over land among people. ${ }^{25}$ Ilyas Ismail states that customary land can be occupied exclusively by the individuals based on the agreement of right regulation. However, the right regulation can be monopolised by the company if the cultivators do not confirm its legal status of law. ${ }^{26}$ This is what the cultivators are afraid of as the conflict occurred in 2010 until 2016. At that time, the village side of Sidawangi attempted to seize "Oro-Oro" land for plantation purpose. ${ }^{27}$ Therefore, the necessity of political law, as crucial law instruments, is critically required by the cultivators to deal with claims directed by the arbitrary of village officers. In other words, political law plays an essential role to claim the land they possess. With the absence of the legality towards a land, in particular "Oro-Oro" land, the State will take over entirely through its authorities or Government Agencies including Regional Governments, State-Owned Enterprises, Persero, and other government legal units to be used for the operation of their particular duties. ${ }^{28}$

\footnotetext{
${ }^{22}$ Satjipto Rahardjo, Ilmu Hukum, Third Edition, Bandung: Citra Adhitya Bhakti, (1991), p. 352.

${ }^{23}$ Compared to Roberto Mangabiera Unger, Gerakan Studi Hukum Kritis, Jakarta: Lembaga Studi dan Advokasi Masyarakat, (1999), p. 24.

${ }^{24}$ Rahayu, Dwi Priyo Ariyanto, Komariah, Sri Hartati, Juahari Syamsiyah, Widiyatmani Sih Dewi, "Dampak Erupsi Gunung Merapi Terhadap Lahan dan Upaya-Upaya Pemulihannya",Cakra Tani-Jurnal Ilmu Ilmu Pertanian, XXIX (1), (2014), p. 67.

${ }^{25}$ Interview with Pandi, Warda, dan Misja as the representative of the "Oro-Oro" land Cultivators in Sidawangi village on January $3^{\text {rd }}, 2018$.

26 See alsoSatrio Nurwicaksono, Pemberian Hak Pengelolaan Atas Tanah dan Potensi Timbulnya Monopoly Swasta Atas Usaha-Usaha Dalam Bidang Agraria: Studi Kasus di Pelabuhan Umum Kabil Batam, Semarang: Diponegoro University, (2008), pp. 1-3.

27 The threat is done by the officials of Sidawangi village recognized as the former criminal. Thus, the researcher does not mention the name but the data are stored though.

28 The 1996 Government Regulation Number 40 Article 1 Number 2 concerning Rights to Cultivate the land, Rights to Build and Use the Land, The 1999 Regulation of the Ministry of Agrarian Affairs/Head of National Land Agency Article 1 Number 14 regarding Procedures of
} 
The Cultivators desperately expect their legal conviction over "Oro-Oro" land. In addition, what they are afraid of is the conflict will potentially occur all over again. There was once an attempt initiated by a village officer. The village officer plotted to switch "Oro-Oro" land for plantation purpose. However, as the village head was rashly replaced the plotting failed. It made the cultivators a bit relieved even though they were still anxious because of the absence of legal conviction concerning the customary right over "OroOro" land. The theory of legal sovereignty precisely contributes to offer the legal conviction, concerning the customary right over "Oro-Oro" land, as expected by the cultivators in Sidawangi village. This theory originally established in the $20^{\text {th }}$ century and it was against the theory of sovereignty. The theory of legal sovereignty was proposed by Hugo Krabbe (Netherlands). ${ }^{29}$ This theory avers that:

a. Law initially originates from legal feelings that occur in most members of the community/society;

b. Law represents the legal feelings that belong to most members of the community/society;

c. Hence, the law is entirely obeyed by the member of the community/society. The political law is a mandatory constituent, as crucial law instruments, to protect the customary right of cultivators over "Oro-Oro" land. The definition of political law, which is equal with state instruments as delineated by Sunarjati Hartono, Soedarto, and Mahfud MD, directs government policy as an instrument of a social experiment. Moreover, it seems that political law is categorized as Top Down. However, the political law, inside the circumstance of "Oro-Oro" land, is categorized as Bottom Up which is by the theory of legal sovereignty proposed by Krabbe where the legal conviction originates from the cultivators. Therefore, this kind of law will be obeyed by a member of the community/society.

The political law concerning the legal conviction over "Oro-Oro" land is indeed a real solution to solve the problem for the government of Sidawangi village and the cultivators of "Oro-Oro" land which are only legalised by mutual agreement. The implementation of legal conviction to elucidate the conflict between the village side and the cultivators is equivalent to the village

StateLand Rights and Management Rights Granting and Cancellation, The 1997 Government Regulation Number 24 Article 1 Number 4.

29 The pioneer of the Sovereignty Law Theory was a distinguished expert from Leiden University, Netherlands, Hugo Krabbe (1857-1936). He studied law and State science in Leiden University and completed his study in 1883 with a thesis entitled "De Burgerlijke Staatsdienst in Nederland" (The Service of Bourgeois State in Netherlands). Several years later, he worked at the Secretariat of Gelderland and Noord Holland Province. He became a professor in Groningen, in 1894, with an inaugural speech entitled "de werkkring van de staat" (State Positions). Later, in 1897, he conducted a report entitled "The Legal Relationship between the State and its officials must be regulated by Law." 
as the holder of the sovereignty theory proposed by Jean Bodin (1576). Also, Jean Bodin was the first theorist who stated that sovereignty was the fundamental constituent of the State. ${ }^{30}$ On the other hand, the cultivators withstand to counter the sovereignty theory by using the framework of citizen sovereignty proposed by John Locke and J. J. Rousseau. In other words, they emphasized putting full sovereignty to entire people in a State.

The legal conviction, indeed, plays an essential role to deal with claims directed by the arbitrary of Sidawangi village officers regarding the customary right over "Oro-Oro" land. It is because the substance employed by the government of Sidawangi village is stronger, in switching rights to business purpose, than the cultivators around "Oro-Oro" land who merely based on mutual agreement. The cultivators' right is essentially protected and guaranteed by the 1945 Constitution Article 18 B Paragraph (2) which states: "The States recognizes and respects customary law community units and their traditional rights as long as they are still alive and relevant with the society development and the principles of the State of the Republic of Indonesia regulated in the Constitution". ${ }^{31}$

Furthermore, the protection and guarantee also occur in 1945 Constitution Article 28 Paragraph (1) which asserts: "Everyone has the right to personal, family, honour, dignity, and property under their control, and also has the right for safety and fortification from the threat of fear to do or not to do something which is not considered as a human right." "32 In addition, in 1945 Constitution Article 33 Paragraph (3) which explains: "The State possesses Earth and water and any kind of natural resources contained within and used for the matter of people/citizen prosperity. ${ }^{33}$ This research implies that it is not a big problem for the cultivators as long as they can live their life prosperously and wealthily by cultivating and managing "Oro-Oro" land which belongs to the State. Instead, the State should protect and guarantee their rights through its Constitution. However, cultivators' lack of knowledge and ignorance about law bring them into a serious problem. As a result, they tend to obey whatever the village side asks even though what they ask are mostly harmful to the cultivators' community in "Oro-Oro" land.

\footnotetext{
${ }^{30}$ The State sovereignty is for its citizens and it cannot be obstructed by law. People in high authority are the source of the law and they are not bound by law. They only obey to celestial law and natural law and are only responsible to God. See also the 1945 Constitution Article 1 Paragraph (3) Third Amendment.

31 The 1945 Constitution of the Republic of Indonesia Article 18 B Paragraph (2) Second Amendments.

32 The 1945 Constitution of the Republic of Indonesia Article 28 Paragraph (1) Second Amendments.

33 The 1945 Constitution of the Republic of Indonesia Article 33 Paragraph (3) Second Amendments.
} 
The cultivators' communities, who refuse to comply, become more desperately anxious as they will be punished and brought to the law court. ${ }^{34}$ According to the investigation, the village side authority also counts on the 1945 Constitution Article 27 Paragraph (1). Which states: "The entire citizens with their position inside the circumstance of law and government must comply with the law and the government deprived of exception". ${ }^{35}$ The term 'deprived of exception' is underlined by the cultivators as it makes them desperately anxious and afraid of dealing with law. What the cultivators need is indeed a knowledge concerning the legal conviction over "Oro-Oro" land. Therefore, the village side arbitrary will consider stopping taking advantage of cultivators' ignorance. The law will only exist through community's consistent assessment and review based on their interests. The law aims to realise an interests' balance between the community/society and government. The people in a community want to protect their own interests and recognise others' benefits which are associated with them. Mutual rights and obligations awareness play a fundamental role to construct political organisations to guarantee public benefits.

Several kinds of literature state that political law always relies on authority. In other words, it requires policies from highest government authority to offer primary legal law for the cultivators. The village side truly implements law as a social experiment to plot "Oro-Oro" land. The implementation of the 1945 Constitution Article 27 Paragraph (1), practically, is not relevant to the expectations within the state of constitutional law. ${ }^{36}$ Hence, the irrelevance, as aforementioned, will lead to constitutional shortcomings for the cultivators concerning the customary right over "Oro-Oro" land. ${ }^{37}$

\section{The Primary Legal Law of "Oro-Oro" Land Cultivators According to Agrarian Law and International Conventions}

\footnotetext{
${ }^{34}$ The interview with "Oro-Oro" land cultivators in Sidawangi village on January $20^{\text {th }}, 2018$.

35 The 1945 Constitution of the Republic of Indonesia Article 28 Paragraph (1) there are no changes in amendment.

${ }^{36}$ The doctrine of constitutional loss consists of five conditions. They can be classified into two classifications explicitly (1) the conditions considered as elements that must be fulfilled; and (2) the conditions which consist of procedures to measure the extent of constitutional loss. The elements, as aforementioned in the first classification, which must be fulfilled are (i) rights and/or authority; (ii) there are losses suffered. On the other hand, the second classification which consists of loss testing procedure is (i) the loss suffered must be specific and actual or at least will potentially emerge; (ii) the relationship emerges by the time the demand is granted, causality between the loss and the law/constitution being tested, and (iii) the loss will not be fixed if the demand is approved. Bisariyadi, "Membedah Doktrin Kerugian Konstitusional", Konstitusi Journal, 14 (1), (2017), pp. 22-44.

${ }^{37}$ The result of the interview with the people of Sidawangi village infers that they will deal with law if they keep cultivating "Oro-Oro" land. They do not even know what law really is. The cultivators always do what the Sidawangi village officials ask even though they feel being abused, January $20^{\text {th }}, 2018$.
} 
During Dutch colonialism, the legal system of land contained legal dualism, namely legal system concerning the customary law for indigenous community and legal system for other communities which are ruled by Western law. ${ }^{38}$ During the Dutch colonialism period in Indonesia, the legal system of land was mostly based on the Dutch and European legal systems by using the concordance principle. ${ }^{39}$ Consequently, the indigenous community's interests were considered insubstantial at that time as it can be seen by several factors as follow:

a. The inexistence of the legal conviction over land;

b. Neglecting the existence of customary law (community) law; and

c. The rights of customary land possession.

"Oro-Oro" land is basically characterized as customary land. "Oro-Oro" land is exclusively cultivated because it is no longer inside the circumstance of customary right. Thus, in other words, "Oro-Oro" land is owned by the cultivators' community. However, there was a difference were during the Dutch Colonialism period there was a tax which on the other hand there was no tax over "Oro-Oro" land under the authority of Sidawangi village. This situation was even getting more confusing for the cultivators as the village side attempted to intimidate them through their unfair policies. The customary right over land, since the Dutch colonialism period, has mandated a tax collected by the Land Office Tax (Dutch: Landrette). What the village side did was identical with Dutch colonisation occupying the people's land. During the Dutch colonialism, the Dutch government annually collected the tax. On the other hand, what the Sidawangi village side did was seizing the cultivators' land without relying on reliable legal village rights.

During the Dutch colonialism, they distributed proof of tax-payments to the tax-payers. The names of the tax-payments were diverse to each region namely Kikitirf or West Java, Petuk/Petok/Pipil for Central of Java and East Java, and Girik for Batavia which is currently known as Jakarta. The government had never distributed proof of rights, in particular, for customary land. Girik was not characterized as the proof rights over land, and its position is equal with Land and Building Tax. The Agrarian Basic Law acknowledged

\footnotetext{
${ }^{38}$ Article 163 of IS (Indische Staatsregeling), the resident of the Dutch East Indies is divided into three groups particularly: (1) European Group; (2) Foreign Eastern Group; and (3) Native Indonesian Group.

${ }^{39}$ Concordance principle refers to a principle which underlies the authorization of European or Dutch law as well as Indonesian Native/indigenous people at that moment. In other words, the European law implemented for Dutch people, formerly, is also legal for native Indonesian people. Hence, it is clear that the concordance is one of Dutch principles/policies which is also implemented for native people in this case Indonesian people http://vivahukum.blogspot.co.id/2014/07/pengertian-asas-konkordansi.html accessed January $20^{\text {th }}, 2018$.
} 
the Customary right over land. It is, indeed, in line with the customary right over "Oro-Oro" land owned and cultivated by the cultivators/people in Sidawangi village. Conflict will potentially occur if the people/cultivators in "Oro-Oro" land do not obtain legal right conviction over "Oro-Oro" land as it happened in Lampung on Monday, January $22^{\text {nd }}, 2018$. At that time, people of Teladas visited the site of customary land of Dente Teladas. Subsequently, they encountered and asked Chief of Rawa Jitu Police to take action and disallow Karya Jitu Mukti people to cultivate and work on that customary land.

However, nowadays, the police do not initiate any actions, and they tend to let Karya Jitu Mukti people cultivate and work on that customary land. ${ }^{40}$ The chronology can be elaborated as follow: "A customary land or termed as a customary right over land of Dante Teladas village, approximately 60 hectares in size, is cultivated by the people of Karya Jitu Mukti Village, Rawa Jitu Selatan Sub-District Tulang Bawang Regency, Lampung Province.The local police were asked by Dante Teladas people to take any actions. Oppositely, Chief of Rawa Jitu Selatan Police declares reinforcement for Karya Jitu Mukti people if the conflict, caused by Kampung Teladas people, occurs. The representative of Tulang Bawang Community Organization Forum (Fortuba), Andika reveals that the customary right over land of Dante Teladas village, located in Karya Jitu Mukti village, has been cultivated by the people nearby (Karya Jitu Mukti Village).

Consequently, the people of Dante Teladas village head to the site of the customary land cultivated by the people nearby. Simultaneously, they also ask the Chief of Rawa Jitu Selatan Police to take any actions but none has been done by the police concerning that incident though. Andri also adds that it is indeed either a great disappointment or displeasure for Dante Teladas people since the Chief of Police and Head of Karya Jitu Mukti village tend to allow their people to cultivate and work on the customary right over land of Dante Teladas village". ${ }^{41}$

There should be, supremely, a relevance of Basic Agrarian Law towards a land under the authority of western rights as well as a land with customary rights. $^{42}$ The relevance above is appropriate with The 1960 Constitution

\footnotetext{
${ }^{40}$ Dante Teladas people are frustrated since the Chief of Police and Head of KaryaJituMukti village tend to obviously allow their people to cultivate and work on the customary right over land of Dante Teladas village. Royhes, Lampungsai.com, "Warga Kampung KJM, Garap Tanah Adat Dente Teladas. Kapolsek Rawajitu Selatan Pasang Badan”, January $26^{\text {th }}, 2018$.

${ }^{41}$ The portrait, concerning customary right over land in Lampung, has confirmed the customary right over land in Sidawangi village also comes to a dead end with the inexistence of clear legal conviction. In other words, the conflict occurs in Lampung is in line with the phenomenon happens in Sidawangi village concerning the importance of clear legal conviction of customary right over "Oro-Oro" land.

${ }^{42}$ See and compare FX. Sumarja, Muhammad Akib, Op.Cit., p. 4.
} 
Number 5 regarding the Basic Agrarian Law. Conversion is an essential requirement to come into the system of the Basic Agrarian Law. Therefore, currently, there is no longer a land identified either as customary or western land. It has become one term based on the 1960 Constitution Number 5 regarding the Basic Agrarian Law. ${ }^{43}$ To enter the arrangement, the previous land characterised either as the customary or western land should be primarily registered or converted. Conversion refers to an arrangement of land rights, which occurs before the Basic Agrarian Law legalization, to enter the internal system of the Basic Agrarian Law. Thus, land registration is very fundamental to accomplish. ${ }^{44}$ According to the land registration related to Government Regulation Number 24 in 1997 considered as a set of attempts initiated by the government consistently, continuously, and regularly. It covers the process of collection, processing, documenting, presentation, and maintenance of either physical or juridical data in form of maps and lists regarding land plots, and flat units. Besides, it also includes the distribution of the proof-rights over the plots land which has already possessed their rights flat units and certain rights they bear.

Therefore, it will provide legal right conviction in the registration of "OroOro" land where during the registration process, there are four conditions that should be fulfilled. They are:

a. Object: land plots with an identity that covers location, boundary, and entire plots land area elaborated in a measurement letter.

b. Subject: the right holder (individual or legal entity) whose its legal conviction written in the book of land as well as in cause of change.

c. Legal relation: the relationship between the subject and people's object or legal entity.

d. Possessing the land plot or burdened to manage it, even losing the rights over it (the types of powers possessed and the burdens over the land rights).

"The State entirely possesses Earth and water and any kind of natural resources contained within and used for the matter of people/citizen prosperity", that is the sentence transcribed in the 1945 Constitution Article 33. Therefore, the State must initiate administrations existed on earth for instance land in narrow sense defined as land registration. It is a mandatory duty the State must carry out to control and supervise the use of land as it is meant to be. Thus, an official rule and evidence are crucially required to be utilized as the legal ownership proof. The implementation of the land registration consists of two phases namely the first registration of land and the second one (derivative). The first registration of land is carried out for the unregistered land (not yet documented in the registration land which is

${ }^{43}$ Darwin Ginting, "Politik Hukum Agraria Terhadap Hak Ulayat Masyarakat Indonesia", Jurnal Hukum \& Pembangunan, 42 (1), (2012), p. 32.

${ }^{44}$ A.P.Parlindungan, Pendaftaran Tanah Di Indonesia, Mandar Maju: Bandung, (1990), p. 1. 
relevant with the 1961 government regulation Number 10 and the 1997 government regulation Number 24). ${ }^{45}$

The regulation concerning the customary right over land should be taken into an account as well. The customary community convention, with regard to a land in part two, delineates that during the regulation implementation in this segment, the government must respect the significance of the specific cultural and spiritual values of the customary community law. It involves their relationship with the land or territory they reside, use, and particularly the collective aspects of this relationship. ${ }^{46}$

The use of terms concerning land should involve the concept of territory which covers the entire environment of the populated areas or, if not, used or cultivated by the related customary law community. ${ }^{47}$ The rights, with regard to what is preserved and possessed by the customary law community toward the lands they have customarily inhabited, must be acknowledged. Furthermore, certain efforts, in an appropriate context, are necessarily required to guarantee and protect the rights of the related customary law community. The efforts, as above-mentioned, are mandatory constituents to use or cultivate the lands they traditionally occupy for their life purposes as well as their traditional activities.

In this case, exceptional considerations are fundamental for the customary law community to cope with the situation encountered by the nomadic community and cultivators in the customary $\mathrm{law}^{48}$. The governments must initiate any necessary actions to identify the lands inhabited by the related customary law community and to guarantee effective protection of their rights with regard to what they have and what they possess. Appropriate procedures should be conducted in a national legal system to resolve claims for land rights proposed by the related customary law community.

The rights of the related customary law community over natural resources related to their lands must be preserved and protected. These rights involve the rights of the customary community law to contribute to the use, management, and conservation of the resources. ${ }^{49}$ The governments must favourably establish or maintain procedures that enable them to consult and

45 The 1997 Government Regulation Number 24, which is the substitution of the 1961 Government Regulation Number 10, is considered no longer relevant with the land conditions in Indonesia. Therefore, new regulation is very necessary to carry out.

${ }^{46}$ Part II regarding Land Article 13 Paragraph (1) K169-Convention on Customary Law Community, 1989.

${ }^{47}$ Part II regarding Land Article 13 Paragraph (2) K169-Convention on Customary Law Community, 1989.

${ }^{48}$ Part II regarding Land Article 14 Paragraph (1) K169-Convention on Customary Law Community, 1989.

${ }^{49}$ Part II regarding Land Article 15 Paragraph (1) and (2) K169-Convention on Customary Law Community, 1989. 
cooperate with the customary law community in a certain situation, where the state retains the ownership of mineral resources or resources existed under the land surface or any other kinds of land resources. The procedures also aim to acquire accurate information concerning what extent the customary community law's interests will be interrupted before the governments carrying out or precede any policies to both explore and exploit their land resources. The related customary law community, if possible, must participate to attain benefits from the activities. They must also accept rational compensation for the possible occurrence of any kinds of loss and damages they will bear as the consequences.

The related customary law community should not be eliminated from the lands they inhabit. If the replacement of the related customary law community is considered to be crucial as an exception, it can only be preceded if they entirely agree with the conditions and consequences offered. If the deal is not made or agreed, the replacement can only be initiated by following the appropriate procedures conducted by national legislation. It also covers collecting public opinions, when necessary, to offer related customary law community an opportunity which plays an essential role to represent their interests contextually. This related customary law community, if possible, has to possess the right to return to their traditional lands immediately. Thus, there will be no more extended claim or reason to move them somewhere else.

If the return is impossible to do, according to the agreement, or the absence of the agreement instead, through the appropriate procedures (this related customary law community), in any occasions, must be given the land which its quality and legal status are at least equivalent with the land they have previously inhabited which is appropriate to fulfil their current requirements and future developments. If this related customary law community prefers to take money or properties compensation, they must be compensated based on their demand under the proper guarantee. Those who are relocated somewhere else, as in line in Paragraph 4, must be fully paid for any kinds of loss or harms during the relocation process. ${ }^{50}$ The procedures arranged by the related customary law community concerning customary right over land among their members must be respected. Reconciliation, with the related customary law community, has to be initiated regularly to consider their capacity to hand over their land possession to the other sides or if not, they shift their rights outside their own communities. Those who do not belong to this community must be prevented from making inappropriate benefits of the customary law community's customs. This anticipation is also beneficial to encounter their

\footnotetext{
${ }^{50}$ Part II regarding Land Article 16 Paragraph (1) (2) (3) (4) and (5) K169-Convention on customary Law Community, 1989.
} 
lack understanding regarding the legislation regulation. Therefore, this prevention is expected to ensure and guarantee the land possession and its use which belongs to this customary law community

\section{Conclusion}

Customary right over "Oro-Oro" land, carried out by the cultivators of Sidawangi village Sumber Sub-District, basically originates from communal land which is exclusively owned by individuals. They are aware that the State owns Oro-Oro land. The conflict occurs when the Sidawangi village officials ask for plants against the cultivators' community will. The cultivators will be punished if they refuse to do what the village side asks. What the Cultivators do is an attempt to obtain a fair political law as their ideal to protect their right over "Oro-Oro" land.

The rights over the land are not explicitly stated in Basic Agrarian Law. However, the cultivators' community possesses a role through the legislation or statute. Therefore, legal politics or political law, as expected, can be realised. The phenomenon occurs in Lampung has portrayed a clear depiction of the conflict occurrence over customary land. The cultivators' community relies on legal protection based on the history of Dutch law, 1945 Constitution, and international community convention. 


\section{A. Book}

\section{Bibliography}

A. P. Parlindungan. (1990). Pendaftaran Tanah Di Indonesia. Bandung: Mandar Maju.

Mahfud MD, Moh. (1998).Politik Hukum di Indonesia. Jakarta: LP3ES.

Nurwicaksono, Satrio. (2008). Pemberian Hak Pengelolaan Atas Tanah dan

Potensi Timbulnya Monopoly Swasta Atas Usaha-Usaha Dalam

Bidang Agraria: Studi Kasus di Pelabuhan Umum Kabil Batam.

Semarang: Universitas Dipenegoro.

Prasetyo, Teguh. (2015). Keadilan Bermartabat Perspektif Teori Hukum.

Bandung: Nusamedia.

Rahardjo, Satjipto. (1991). Ilmu Hukum. Bandung: Citra Adhitya Bhakti.

Soedarto. (1983). Hukum Pidana dan Perkembangan Masyarakat dalam Kajian Hukum Pidana. Bandung: SinarBaru.

Unger, Roberto Mangabiera. (1999). Gerakan Studi Hukum Kritis. Jakarta: Lembaga Studi dan Advokasi Masyarakat.

\section{B. Journal, Article and Dictionary}

Aermadepa, "Perlindungan Hak Konstitusional Masyarakat Hukum Adat Minangkabau dalam Pelaksanaan Gadai Tanah Pertanian", Jurnal Konstitusi, 13 (3), (2016), p. 603, https://doi.org/10.31078/jk1336 .

Bisariyadi, "Membedah Doktrin Kerugian Konstitusional", Jurnal Konstitusi, 14 (1), (2017), pp. 22-44. https://doi.org/10.31078/jk1412 .

Darwin Ginting, "Politik Hukum Agraria Terhadap Hak Ulayat Masyarakat Indonesia", Jurnal Hukum \& Pembangunan, 42 (1), (2012), p. 32, https://doi.org/10.21143/jhp.vol42.no1.284 .

FX. Sumarja, Muhammad Akib, "Forest Resources Access Moro-Moro Farmers at Register 45 Lampung", Fiat Justisia: Jurnal Ilmu Hukum, 12(1), (2018), p. 10, https://doi.org/10.25041/fiatjustisia.v12no1.980 .

Ilyas Ismail, "Kedudukan dan Pengakuan Hak Ulayat Dalam Sistem Hukum Agraria Nasional", Jurnal KANUN, 12 (1), (2010), p. 675.

Indah Mahniasari, "Pendaftaran Tanah Adat", Jurnal Al' Adl, 5 (9), (2013), p. 23.

Irsyad Martias, "Implikasi Perubahan Tata Guna Lahan Terhadap Dinamika Ekonomi-Sosial Masyarakat Gunung Kidul: Suatu Kajian Antropologi

Keruangan”, Jurnal BioKultur, 3(1),(2014), pp. 292-315.

Kamus Besar Bahasa Indonesia, https://www.kbbi.web.id/hak. Accessed on February 22, 2018.

Muhammad Zakie, "Konflik Agraria Yang Tak Pernah Reda", Jurnal Legality, 1 (1), (2016), p. 45, https://doi.org/10.22219/jihl.v24i1.4256 . 
Muslim Andi Yusuf, "Kepastian Hukum Hak Masyarakat Hukum Adat Atas

Tanah dan Sumber Daya Alam", National Seminar Proceeding Cokroaminoto University, 2 (1), p. 675.

Rahayu, Dwi Priyo Ariyanto, Komariah, Sri Hartati, Juahari Syamsiyah, Widiyatmani Sih Dewi, "Dampak Erupsi Gunung Merapi Terhadap Lahan dan Upaya-Upaya Pemulihannya”, Cakra Tani-Jurnal Ilmu Ilmu Pertanian, XXIX (1), (2014), p. 675, https://doi.org/10.20961/carakatani.v29i1.13320 .

Sarip, "Produk Hukum Pengkebirian Pemerintahan Desa", Jurnal Hukum \& Pembangunan, 49 (1),(2019), p. 63.

Wahyu Nugroho, "Politik Hukum Pasca Putusan Mahkamah Konstitusitas Pelaksanaan Pemilu dan Pemilukada di Indonesia", Jurnal Konstitusi, 13 (3), (2016), pp. 480-502, https://doi.org/10.31078/jk1331 .

\section{Legislations}

Customary Law Community Convention 1989

Republic of Indonesia, 1945 Constitution Amendments 1, 2, 3, 4.

The Republic of Indonesia, Basic Agrarian Law Number 5 of 1960.

The Republic of Indonesia, Government Regulation Number 24 of 1997 concerning Land Registration

The Republic of Indonesia, Government Regulation Number 40 of 1996 concerning Land Use Rights, Land Use Rights and Land Use Rights,

The Republic of Indonesia, Minister of Forestry Regulation Number: P. 49 / Menhut-II / 2008 concerning Village Forests.

The Republic of Indonesia, Regulation of the Minister of Agrarian Affairs / Head of National Land Agency Number 9 of 1999 concerning Procedures for Granting and Cancellation of State Land Rights and Management Rights.

\section{Internet and Interview}

Jurisprudence tanggal 12 Mei 2010 http://bungalegal.blogspot.co.id/2010/05/definisi-politik-hukum-danpolitik.html.Accessed on February $1^{\text {st }}, 2018$.

Royhes, Lampungsai.Com," Warga Kampung KJM, Garap Tanah Adat Dente Teladas. Kapolsek Rawajitu Selatan Pasang Badan", Accessed on January 26, 2018.

Interview, small discussion with Oro-Oro landowners in Sidawangi Village on January 20, 2018.

Interview with the farmers of Tanah Oro-Oro in Sidawangi Village on January 20, 2018. 
Interview with Pandi, Prior to felling, there had actually been a discussion with residents of the Oro-Oro land-owner, but in his practice it was not in accordance with the 18 December 2017 agreement.

Tarsan, Misja, Karwasih, Sanding, Tani, and Rusmana interviews on January 21, 2018.

Interview with Warda, Misja, Miah, Pandi, and Asda as the owner of the OroOro Land with evidence of community agreement on land rights with boundaries was also jointly established by residents of Sidawangi village on 2 December 2017.

Interview, Villagers of Sidawangi Pandi, Warda, and Misja, as cultivators of the Oro-Oro land on January 3, 2018. 
